OPEN ACCESS

Edited by:

Javier Diéguez-Uribeondo, Real Jardín Botánico (RJB), Spain

Reviewed by:

Diana Minardi,

Centre for Environment, Fisheries and Aquaculture Science (CEFAS),

United Kingdom

Enrique Lara,

Consejo Superior de Investigaciones

Cientificas (CSIC), Spain

${ }^{*}$ Correspondence: Valentina Curin v.curini@izs.it

Specialty section:

This article was submitted to Evolutionary and Population Genetics, a section of the journal

Frontiers in Ecology and Evolution

Received: 21 August 2020 Accepted: 28 May 2021

Published: 28 June 2021

Citation:

Di Domenico M, Curini V Caprioli R, Giansante C, Mrugała A,

Mojžišová $M$, Cammà $C$ and Petrusek A (2021) Real-Time PCR

Assays for Rapid Identification of Common Aphanomyces astaci

Genotypes

Front. Ecol. Evol. 9:597585. doi: 10.3389/fevo.2021.597585

\section{Real-Time PCR Assays for Rapid Identification of Common Aphanomyces astaci Genotypes}

\author{
Marco Di Domenico', Valentina Curini ${ }^{1 *}$, Riccardo Caprioli ${ }^{1,2}$, Carla Giansante', \\ Agata Mrugała ${ }^{3,4,5,6}$, Michaela Mojžišová ${ }^{3}$, Cesare Cammà ${ }^{1}$ and Adam Petrusek ${ }^{3}$

\footnotetext{
${ }^{1}$ Istituto Zooprofilattico Sperimentale dell'Abruzzo e del Molise G. Caporale, Teramo, Italy, ${ }^{2}$ Agenzia Regionale Protezione Ambientale del Lazio, Rome, Italy, ${ }^{3}$ Department of Ecology, Faculty of Science, Charles University, Prague, Czechia, ${ }^{4}$ Leibniz-Institute of Freshwater Ecology and Inland Fisheries (IGB), Berlin, Germany, ${ }^{5}$ Department of Biology, Chemistry, Pharmacy, Institute of Biology, Freie Universität Berlin, Berlin, Germany, ${ }^{6}$ Berlin-Brandenburg Institute of Advanced Biodiversity Research, Berlin, Germany
}

The oomycete Aphanomyces astaci is the etiologic agent of crayfish plague, a disease that has seriously impacted the populations of European native crayfish species. The introduction of non-indigenous crayfish of North American origin and their wide distribution across Europe have largely contributed to spread of crayfish plague in areas populated by indigenous crayfish. Tracking $A$. astaci genotypes may thus be a useful tool for investigating the natural history of crayfish plague in its European range, as well as the sources and introduction pathways of the pathogen. In this study, we describe the development of real-time PCR TaqMan assays aiming to distinguish the five genotype groups of $A$. astaci (A-E) previously defined by their distinct RAPD patterns. The method was evaluated using DNA extracts from pure $A$. astaci cultures representing the known genotype groups, and from $A$. astaci-positive crayfish clinical samples collected mostly during crayfish plague outbreaks that recently occurred in Central Italy and Czechia. The assays do not cross-react with each other, and those targeting genotype groups A, B, $D$, and $E$ seem sufficiently specific to genotype the pathogen from infected crayfish in the areas invaded by $A$. astaci (particularly Europe). The unusual $A$. astaci genotype "SSRUp" documented from crayfish plague outbreaks in Czechia and chronically infected Pontastacus leptodactylus in the Danube is detected by the group B real-time PCR. The assay originally developed to detect group $\mathrm{C}$ (one not yet documented from crayfish plague outbreaks) showed cross-reactivity with Aphanomyces fennicus; the A. astaci genotype "rust1" described in the United States from Faxonius rusticus is detected by that assay as well. Analyses of additional markers (such as sequencing of the nuclear internal transcribed spacer or mitochondrial ribosomal subunits) may complement such cases when the real-time PCR-based genotyping is not conclusive. Despite some limitations, the method is a robust tool for fast genotyping of $A$. astaci genotype groups common in Europe, both during crayfish plague outbreaks and in latent infections. 


\section{INTRODUCTION}

Crayfish plague is a disease of freshwater crayfish caused by the oomycete Aphanomyces astaci, which has been endangering the populations of indigenous crayfish throughout Europe and adjacent regions for over 150 years (Alderman, 1996; Holdich et al., 2009; OIE (World Organisation for Animal Health), 2019). Recently, the presence of $A$. astaci in the wild has been documented from Brazil (Peiró et al., 2016), Indonesia (Putra et al., 2018), and Japan (Mrugała et al., 2017a), with confirmed mortalities of the endemic Japanese crayfish Cambaroides japonicus (Martín-Torrijos et al., 2018). Furthermore, the disease has caused mortalities in aquacultures of susceptible crayfish hosts (Hsieh et al., 2016). Its negative impacts thus also extend to biogeographic regions other than the Western Palaearctic.

The original hosts of the crayfish plague pathogen A. astaci are North American freshwater crayfish species, such as the signal crayfish Pacifastacus leniusculus, red swamp crayfish Procambarus clarkii, and spiny-cheek crayfish Faxonius limosus (Unestam and Weiss, 1970; Vey et al., 1983; Diéguez-Uribeondo et al., 1995) which are particularly widespread as invaders in Europe (Kouba et al., 2014). North American crayfish coevolved with this oomycete and only succumb to crayfish plague under particular conditions (e.g., Unestam, 1969, 1972; DiéguezUribeondo and Söderhäll, 1993; Diéguez-Uribeondo et al., 1995), but can act as carriers of the infection [e.g., Persson and Söderhäll, 1983; Diéguez-Uribeondo and Söderhäll, 1993; Jussila et al., 2015; OIE (World Organisation for Animal Health), 2019]. Recently, with the development of suitable molecular methods, chronic infections in populations of crayfish species that are generally considered susceptible but had not experienced mass mortalities or other symptoms of acute crayfish plague were also documented (see a review in Svoboda et al., 2017).

The first wave of crayfish mass mortalities across Europe seem to have occurred in the second half of the nineteenth and early twentieth centuries, spreading through native populations of European crayfish (reviewed in Alderman, 1996) but without any documented information about the presence of the original pathogen carriers. The subsequent introduction of North American crayfish species to Europe and their current wide distribution across the continent (Holdich et al., 2009; Kouba et al., 2014) have been the cause of past and recent spread of crayfish plague in areas populated by indigenous European species (e.g., Huang et al., 1994; Bohman et al., 2006; DiéguezUribeondo, 2006; Kozubíková et al., 2011a; Schrimpf et al., 2012; Filipová et al., 2013; Viljamaa-Dirks et al., 2013; KozubíkováBalcarová et al., 2014; Rezinciuc et al., 2014; Vrålstad et al., 2014; Martín-Torrijos et al., 2019) and have also led to the introduction of pathogen genotypes different from those involved in early crayfish plague outbreaks (Rezinciuc et al., 2015).

Molecular typing by the random amplified polymorphic DNA (RAPD) of $A$. astaci axenic laboratory cultures (Huang et al., 1994) has allowed the identification of five distinct genotype groups, labeled alphabetically from A to E (reviewed in Rezinciuc et al., 2015). The application of genotyping markers to clinical samples (i.e., DNA isolates from infected crayfish), particularly the analysis of microsatellite loci (Grandjean et al., 2014) and sequencing of mitochondrial ribosomal genes (Makkonen et al., 2018), allowed the discovery of additional variation among A. astaci strains, both in outbreaks of the disease (Grandjean et al., 2014; Martín-Torrijos et al., 2018) and from non-symptomatic hosts (Mrugała et al., 2017a; Martín-Torrijos et al., 2018; Panteleit et al., 2019; Martín-Torrijos et al., 2021). However, the vast majority of crayfish plague outbreaks in Europe analyzed so far have been linked to one of the four RAPD-defined genotype groups either isolated from one of the widespread crayfish invaders (groups B, D, E; Huang et al., 1994; Diéguez-Uribeondo et al., 1995; Kozubíková et al., 2011b) or associated with historical mortalities (group A; Huang et al., 1994). Tracking A. astaci genotypes or genotype groups may thus be a useful tool for investigating the natural history of crayfish plague in its invaded range, as well as the sources and introduction pathways of the pathogen.

The data on the distribution of $A$. astaci genotypes in Europe and adjacent regions, analyzed from various sources including axenic laboratory cultures, crayfish mass mortalities, and chronically infected crayfish hosts, were recently summarized by Ungureanu et al. (2020). Most information available from Europe so far comes from crayfish mass mortalities, which have been analyzed by various molecular approaches that should allow matching results to the original RAPD-defined genotype groups (see below). In particular, causative agents of crayfish plague outbreaks have been genotyped in regions where crayfish plague is considered a major threat to indigenous crayfish conservation, and thus research has been intensive in the past two decades. It is important to keep in mind that the diversity of $A$. astaci in its native range is largely unexplored, and substantial additional variation has been already discovered since this oomycete became studied in other natural hosts (Panteleit et al., 2019; MartínTorrijos et al., 2021).

The distribution pattern of $A$. astaci genotype groups, as identified by RAPD analysis of axenic cultures or by other DNAbased methods from clinical samples, is uneven across Europe (see map in Ungureanu et al., 2020). Group A, presumably the first to have been introduced there in the 19th century (Huang et al., 1994), has been frequently detected in Fennoscandia and also caused recent mortalities in Czechia, Croatia, Bosnia and Herzegovina, and Central Italy (Caprioli et al., 2013, 2018; Viljamaa-Dirks et al., 2013; Kozubíková-Balcarová et al., 2014; Vrålstad et al., 2014; Maguire et al., 2016; Mrugała et al., 2017b). Other genotype groups, which have been associated with American crayfish host taxa introduced to Europe in the late 19th and 20th centuries, follow to some extent their distribution across the continent (Kouba et al., 2014). Group B, originally isolated from the signal crayfish P. leniusculus (Huang et al., 1994), is widespread, being associated with at least some mortalities in most European regions from which genotyping data are available (e.g., Vrålstad et al., 2014; Caprioli et al., 2018; Martín-Torrijos et al., 2019). Group D, isolated from the red swamp crayfish P. clarkii (Diéguez-Uribeondo et al., 1995), has mostly been detected in southwestern Europe, where this crayfish invader is particularly widespread (e.g., Caprioli et al., 2018; MartínTorrijos et al., 2019). Recently, group D strains were also associated with mortalities in Czechia (Mojžišová et al., 2020), 
with aquarium-kept crayfish (known to host this group; Mrugała et al., 2017a; Makkonen et al., 2018) implicated as likely sources of the infection. Group $\mathrm{E}$ was originally isolated from the spiny-cheek crayfish F. limosus (Kozubíková et al., 2011a). Its crayfish host is widespread from France across Central Europe to the Baltic countries (Kouba et al., 2014), which corresponds to regions where mortalities associated with group $\mathrm{E}$ have been reported (Grandjean et al., 2014; Kaldre et al., 2017; Mojžišová et al., 2020).

It is worth noting, however, that most mortalities associated with crayfish plague have not yet been examined by pathogen genotyping, and no data are available from some European regions (such as Poland, or most of the Balkans and Eastern Europe). It is thus certain that the distribution of known genotype groups is substantially wider than so far documented. Furthermore, links between $A$. astaci genotypes and the host taxa serving as sources of the infection are rather presumed than well documented, as genotyping of the pathogen from the invasive populations of its American hosts has not been performed frequently (Ungureanu et al., 2020), and horizontal transfer of the pathogen upon contact with non-symptomatic hosts seems possible both in captivity and in the wild (Mrugała et al., 2015; James et al., 2017).

Interestingly, recently obtained data on the $A$. astaci distribution and genotypes from Eastern Europe and Turkey, summarized in Ungureanu et al. (2020), come mostly from chronic infections of the narrow-clawed crayfish Pontastacus leptodactylus indigenous to those regions. In this host, at least three different strains have been documented, including those of genotype groups A and B (e.g., Kokko et al., 2018) as well as the enigmatic genotype "SSR-Up" (Panteleit et al., 2018), characterized so far by a specific allele combination of microsatellite markers and otherwise known only from mass mortalities in Czechia (Grandjean et al., 2014; Mojžišová et al., 2020).

As already mentioned, A. astaci genotyping has been accomplished using various molecular typing techniques. Two of these, RAPD analysis (Huang et al., 1994; Diéguez-Uribeondo et al., 1995; Kozubíková et al., 2011a) and amplified fragment length polymorphism (AFLP) (Rezinciuc et al., 2014), require axenic cultures of the pathogen. However, the use of highthroughput sequencing and bioinformatic analyses has allowed the development of alternative genotyping methods suitable for processing mixed genomic DNA samples extracted directly from infected crayfish tissues. The first of these was an analysis of microsatellite markers (Grandjean et al., 2014). The variation in these microsatellite loci is sufficient to differentiate among all A. astaci genotype groups identified to date in Europe (Grandjean et al., 2014; Panteleit et al., 2018, 2019). The method also allows the retrospective analyses of the disease natural history, pathogen sources, and most likely introduction pathways, based on historical samples preserved from past crayfish plague outbreaks (e.g., Grandjean et al., 2014; Vrålstad et al., 2014; Kaldre et al., 2017; Caprioli et al., 2018).

More recently, Makkonen et al. (2018) published a genotyping method based on the sequencing of phylogenetically informative mitochondrial ribosomal markers (small and large ribosomal subunits, rnnS and rnnL) amplified by conventional PCR; this method allows the distinguishing of $A$. astaci from other known related oomycete species, as well as the differentiation of known RAPD-defined genotype groups except for group C (Makkonen et al., 2018; Casabella-Herrero et al., 2021). Whole-genome analysis of $A$. astaci strains representing the five currently known genotype groups allowed Minardi et al. (2018) to identify genomic regions presumably unique to each representative strain and to develop genotype-specific primers for a conventional PCR-based genotyping assay. In order to improve the sensitivity, the same group published an alternative method based on restriction fragment length polymorphism (RFLP) of mitochondrial markers (Minardi et al., 2019).

In this study, we describe the development and application of a new method based on real-time PCR as an alternative approach to currently available methods for the quick identification of common $A$. astaci genotype groups causing crayfish plague outbreaks in Europe. This method is applicable on both pure cultures and clinical crayfish samples. Since its appearance two decades ago, real-time PCR has been used as a powerful tool for genotyping (Alker et al., 2004; Birdsell et al., 2014). This method is a closed-tube system requiring no post-PCR processing, reducing the likelihood of laboratory cross-contamination by amplified products. Moreover, real-time PCR often has high specificity and sensitivity. Considering all these benefits, we developed TaqMan real-time PCR assays targeting all five genotype groups, designed on the genomic regions previously described by Minardi et al. (2018). The method was evaluated using DNA extracts from pure A. astaci cultures representative of the known genotype groups, and from A. astaci-positive clinical crayfish samples collected during crayfish plague outbreaks that recently occurred in Central Italy and Czechia or representing crayfish hosts chronically infected by this pathogen.

\section{MATERIALS AND METHODS}

DNA from all P. clarkii individuals collected in Italy and used in this study were isolated from the crayfish soft abdominal cuticle by means of a Maxwell 16 Tissue DNA Purification Kit (Promega, Madison, WI) following the manufacturer's guidelines. Other DNA isolates originating from infected crayfish or from axenic laboratory cultures of oomycetes were reused from previous studies (see below).

The anonymous locus sequences (MH016383, MH016384, MH016385, MH016386, MH016387) published by Minardi et al. (2018) as being specific for the $A$. astaci strains representing genotype groups A-E, respectively, were used to design five TaqMan real-time PCR assays in Primer Express software 3.0.1 (Applied Biosystems, Foster City, CA). These assays are further referred to by the respective letter, although some of them amplify a wider range of targets (see "Results"). The sequences of primer pairs and probes of each of the assays are listed in Table $\mathbf{1 .}$

PCR reactions were performed on a QuantStudio 7 Flex Real-Time PCR System (Applied Biosystems) in fast mode with the following protocol: initial denaturation at $95^{\circ} \mathrm{C}$ for $20 \mathrm{~s}$, followed by 45 cycles of denaturation at $95^{\circ} \mathrm{C}$ for $1 \mathrm{~s}$ and 
TABLE 1 | Sequences of primers and probes for the real-time PCR assays designed to amplify specific genomic regions of strains representing Aphanomyces astaci genotype groups A-E.

\begin{tabular}{|c|c|c|c|}
\hline Assay & Oligoname & Sequence $\left(5^{\prime}-3^{\prime}\right)$ & Amplicon size \\
\hline \multirow[t]{3}{*}{ A } & Aast_A_fwd & CAGTCCCACGAGCCGAAA & $71 \mathrm{bp}$ \\
\hline & Aast_A_rev & CCATCGCTGCTTGCAAGAC & \\
\hline & Aast_A_probe & $\begin{array}{c}\text { JOE-TCGCGCTTCTAGTGCTTCTA } \\
\text { TTCGATCCA-TAMRA }\end{array}$ & \\
\hline \multirow[t]{3}{*}{$B$} & Aast_B_fwd & AACAAGCGACCTTCCATTTCA & $66 \mathrm{bp}$ \\
\hline & Aast_B_rev & TाTCGGAGCAGCCAGATTG & \\
\hline & Aast_B_probe & $\begin{array}{c}\text { FAM- } \\
\text { AACGCAACTCGCACAATGGAACGA- } \\
\text { TAMRA }\end{array}$ & \\
\hline \multirow[t]{3}{*}{ C } & Aast_C_fwd & CAACATACCAGTTGCGAACGA & $77 \mathrm{bp}$ \\
\hline & Aast_C_rev & GATTTCATCTACCGAGCTTCAACA & \\
\hline & Aast_C_probe & $\begin{array}{c}\text { FAM-CTTGCGTTCATGCTCGATTTCG } \\
\text { TCTAATTC-TAMRA }\end{array}$ & \\
\hline \multirow[t]{3}{*}{$\mathrm{D}$} & Aast_D_fwd & AATाTGACGATGTGCAATGGAA & $67 \mathrm{bp}$ \\
\hline & Aast_D_rev & TCCGCTITCATITGCAAATATT & \\
\hline & Aast_D_probe & $\begin{array}{c}\text { FAM-CCGTTTCAACAAACAGTGG- } \\
\text { TAMRA }\end{array}$ & \\
\hline \multirow[t]{3}{*}{$E$} & Aast_E_fwd & TGCCTGGAGTATTGCCTGAAT & $74 \mathrm{bp}$ \\
\hline & Aast_E_rev & TACGCGCAAACCTATCTCTGAA & \\
\hline & Aast_E_probe & $\begin{array}{c}\text { JOE-CGTGCGAGCAAAAGCCT } \\
\text { CAACTCG-TAMRA }\end{array}$ & \\
\hline
\end{tabular}

annealing/extension at $60^{\circ} \mathrm{C}$ for $20 \mathrm{~s}$. The $20-\mu \mathrm{l}$ reaction volume contained final concentrations of $1 \times$ GoTaq Probe qPCR Master Mix (Promega), $0.5 \mu \mathrm{M}$ forward primer, $0.5 \mu \mathrm{M}$ reverse primer, $0.2 \mu \mathrm{M}$ TaqMan probe, $5 \mu \mathrm{l}$ DNA template, and nuclease-free water up to volume. No Template Control (NTC) was used for every assay. The fluorescent signal was measured during the annealing step of the reaction.

Specificity was tested on DNA isolates from axenic laboratory strains of genotype groups A-E (Table 2), which were also used as positive controls in every PCR run, and on DNA isolates from axenic cultures of various other oomycete taxa isolated from crayfish. These included, in particular, multiple Aphanomyces strains: A. fennicus (M6/1), a recently described apparently avirulent species closely related to $A$. astaci, which cross-reacts with the real-time PCR-based $A$. astaci detection (Viljamaa-Dirks and Heinikainen, 2019), A. laevisrepetans (strain SAP761; Kozubíková-Balcarová et al., 2013), six strains of two Aphanomyces lineages (T10, T2S1, T2S2, T2S3, T2UN1, T2UN2) isolated from Lake Tahoe signal crayfish P. leniusculus by Makkonen et al. (2019), and A. frigidophilus (SAP233, SAP472) isolated from Spanish white-clawed crayfish Austropotamobius pallipes (Ballesteros et al., 2006; DiéguezUribeondo et al., 2009). We also included DNA from strains of Saprolegnia ferax (SAP691, Li19), S. hypogyna (Li16), S. parasitica (SAP694), S. australis (SAP684), Pythium sp. (Li18, Li20), and an unidentified Saprolegniaceae strain (Li01), all of these originally cultivated from crayfish bodies (Kozubíková-Balcarová et al., 2013). Furthermore, two additional Aphanomyces species parasitizing other organisms, a plant pathogen $A$. cochlioides and a fish pathogen $A$. invadans (SAP308; Diéguez-Uribeondo et al., 2009), were tested for the specificity of the assays.

The method was then applied to DNA isolates from $A$. astaciinfected crayfish of various origins (Table 3): 13 DNA isolates from 11 crayfish plague outbreaks affecting noble crayfish Astacus astacus or stone crayfish Austropotamobius torrentium recorded recently in Czechia (Kozubíková et al., 2008; KozubíkováBalcarová et al., 2014; Mojžišová et al., 2020), on 26 DNA isolates of white clawed crayfish (A. pallipes) from Italian outbreaks (mostly reported in Caprioli et al., 2018), 26 DNA isolates from infected crayfish alien to Italy (P. leptodactylus, P. clarkii), and a DNA isolate from an infected individual of the rusty crayfish Faxonius rusticus from the United States (Panteleit et al., 2019). The presence of $A$. astaci DNA in these samples was confirmed and quantified by real-time PCR according to Vrålstad et al. (2009), with details of the protocol provided in Caprioli et al. (2018). In samples with sufficiently high agent levels (from A3 to A7), the pathogen had also been genotyped by microsatellite markers following Grandjean et al. (2014).

The tested samples also included DNA isolates from crayfish infected by two unusual $A$. astaci genotypes that differ at microsatellite markers from so far characterized strains of known RAPD-defined genotype groups. The first was the specific "SSR-Up" genotype from an outbreak in Úpořský brook (Czechia), which is more similar to strains of RAPD-defined group B at the studied microsatellite loci (Grandjean et al., 2014; Mojžišová et al., 2020), but assigned to mitochondrial haplogroup A based on rnnS and rnnL sequences (Makkonen et al., 2018). The second such genotype is "rust1," also belonging to haplogroup A, documented from two US populations of F. rusticus and isolated to axenic cultures from one of them (Panteleit et al., 2019).

Finally, assays A and B, labeled with different dyes (Table 1), were optimized for duplex real-time PCR. The same approach was taken for assays $\mathrm{D}$ and $\mathrm{E}$, while assay $\mathrm{C}$ was performed separately. The ROX dye (6-carboxy-X-rhodamine) was used as passive reference in every reaction mix. For the duplex reactions, the 20- $\mu$ l reaction volume contained final concentrations of $1 \times$ GoTaq Probe qPCR Master Mix (Promega), $0.5 \mu \mathrm{M}$ of both forward primers, $0.5 \mu \mathrm{M}$ of both reverse primers, $0.2 \mu \mathrm{M}$ of both TaqMan probes, $5 \mu$ l DNA template, and nuclease-free water to reach the final volume. The PCR cycling conditions were identical to those described above. A paired $t$-test was used to compare simplex and duplex real-time PCR results.

\section{RESULTS}

All the reference axenic cultures of $A$. astaci were assigned to their respective genotype group by the newly developed real-time PCR assays (Table 2). Moreover, no-template controls and DNA from all but one isolate of non-target taxa did not produce any detectable fluorescence signal, demonstrating the high specificity of the test (data not shown). The exception was the DNA isolate from $A$. fennicus, which yielded a positive signal with the realtime PCR assay originally developed for group C. 
TABLE 2 | Axenic cultures of $A$. astaci strains used to validate the new real-time PCR assays.

\begin{tabular}{|c|c|c|c|c|c|c|c|c|c|}
\hline \multirow[t]{2}{*}{ Isolate } & \multirow[t]{2}{*}{ Origin } & \multirow[t]{2}{*}{ Crayfish host } & \multirow[t]{2}{*}{ Genotype group } & \multirow[t]{2}{*}{ ITS $^{a}(C t)$} & \multicolumn{5}{|c|}{ Real-time PCR genotyping ${ }^{b}(C t)$} \\
\hline & & & & & A & B & C & D & $\mathbf{E}$ \\
\hline Al7 & Armenia $^{\mathrm{c}}$ & Pontastacus leptodactylus & $A$ & 27.7 & 33.5 & & & & \\
\hline Pec14 & Czechia & Astacus astacus & B & 27.0 & & 34.6 & & & \\
\hline Kv1 & Canada $^{\mathrm{d}}$ & Pacifastacus leniusculus & C & 21.7 & & & 28.5 & & \\
\hline Fin183 & Ornamental trade ${ }^{e}$ & Procambarus virginalis & $\mathrm{D}$ & 18.6 & & & & 22.5 & \\
\hline Li10 & Czechia & Astacus astacus & $E$ & 23.7 & & & & & 33 \\
\hline
\end{tabular}

${ }^{a}$ Ct values obtained from the real-time PCR targeting the nuclear internal transcribed spacer (ITS) region (Vrålstad et al., 2009).

${ }^{\mathrm{b}} \mathrm{Ct}$ values obtained from the real-time PCR genotyping assays described in this study.

c/solated in Czechia from narrow-clawed crayfish presumably originating from Armenia (Becking et al., 2015).

d/solated in Sweden from signal crayfish that originated from Pitt Lake, Canada (Huang et al., 1994).

e/solated in Finland from a crayfish purchased in a German pet shop (Mrugała et al., 2015).

The genotypes determined by the five assays on DNA extracted directly from crayfish cuticles corresponded with assignments to genotype groups based on the microsatellite analysis. The two "SSR-Up" samples yielded positive signals in the assay developed in this study for genotype group $B$. The sample from F. rusticus infected by the A. astaci "rust1" genotype yielded a positive signal with assay $\mathrm{C}$ (Table 3 ).

The novel real-time PCR method succeeded in genotyping the pathogen in four DNA isolates from infected crayfish specimens for which the microsatellite analysis failed. However, for 17 samples with low pathogen DNA concentrations that were detectable by the real-time PCR assay targeting the ITS region (Vrålstad et al., 2009), neither our real-time PCR assays nor microsatellite analyses were able to determine the genotype group (Table 3).

Combining the real-time PCR assays in duplex reactions was successful. The genotype of all 12 samples tested by the duplex assays was correctly determined without any cross-amplification, and with no significant drop in cycle threshold $(\mathrm{Ct})$ values $[t(11)=-0.45 ; p=0.32]$ when compared to those obtained by simplex assays (Table 4).

\section{DISCUSSION}

Molecular typing of $A$. astaci strains, which differentiates distinct genotype groups, contributes to a better understanding of the relationship between this pathogen and its host taxa. It also has practical implications, as the identification of $A$. astaci genotypes can assist in tracing sources of infection during crayfish plague outbreaks (e.g., Vrålstad et al., 2014; Maguire et al., 2016; Mrugała et al., 2017b; Martín-Torrijos et al., 2019) and in chronically infected populations (e.g., Kokko et al., 2018).

RAPD analysis was the first genotyping approach applied to A. astaci isolates (Huang et al., 1994) but could be applied only to axenic laboratory cultures. Since then, the challenge has been to develop genotyping tools that can be applied directly to DNA isolates from crayfish tissues, avoiding the time-consuming and often unsuccessful isolation of the agent (Oidtmann et al., 1999; Cammà et al., 2010). Based on microsatellite analysis, Grandjean et al. (2014) provided a method to distinguish the five currently known genotype groups and uncover some additional variation.
This technique is PCR-based, so even intermediate quantities of template DNA occurring in asymptomatic carriers can be genotyped. However, microsatellite analysis can suffer from inter-laboratory reproducibility, including a failure to establish a successful workflow or inconsistent allele scoring. Indeed, recent papers have reported minor differences in genotyped allele sizes from reference strains (compare Panteleit et al., 2018, 2019 with Mojžišová et al., 2020). In addition, the presence of unusual patterns may lead to uncertain results, especially when applied directly to field-collected samples. This may be caused by apparently novel genotypes (Kozubíková-Balcarová et al., 2014; Panteleit et al., 2019), presumed minor variation within the known RAPD-defined genotype groups (James et al., 2017; Mrugała et al., 2017a; Caprioli et al., 2018), or A. astaci coinfections by different strains (Maguire et al., 2016). Possibly, the presence of DNA of other related oomycetes may also contribute to inconclusive results, as some of the markers are not species-specific (Grandjean et al., 2014; but note the typesetting error in the Aast10 locus rectified in Mojžišová et al., 2020). The method also suffers from low success once the pathogen DNA concentrations drop to agent level A3 and below (Grandjean et al., 2014; Caprioli et al., 2018).

Recently, in order to improve the genotyping sensitivity, two alternative methods based on multicopy mitochondrial DNA markers have been successfully developed and applied (Makkonen et al., 2018; Martín-Torrijos et al., 2018, 2021; Minardi et al., 2019; Butler et al., 2020; Casabella-Herrero et al., 2021). Sequence analysis of the two ribosomal subunits ( $\mathrm{rnnS}$ and $\mathrm{rnnL}$ ) did not allow differentiating between RAPDdefined genotype groups $\mathrm{A}$ and $\mathrm{C}$ (which belong to the same haplogroup A), but it did reveal additional variation within group D (Makkonen et al., 2018; Martín-Torrijos et al., 2018). The sensitivity of this haplotyping approach has not been quantified, but it has been successfully applied to agent level A3 isolates, i.e., with relatively low levels of the pathogen DNA in the sample (Kokko et al., 2018; Panteleit et al., 2018). The RFLP-based assay targeting genotype-specific single-nucleotide polymorphisms in mitochondrial DNA (Minardi et al., 2019) demonstrated high sensitivity but lacked specificity. In particular, A. astaci genotype group $\mathrm{D}$, widespread from southwestern to central Europe (Ungureanu et al., 2020) and also causing crayfish plague outbreaks in Japan (Martín-Torrijos et al., 2018), showed 
TABLE 3 | Direct genotyping of mixed DNA isolates from field samples.

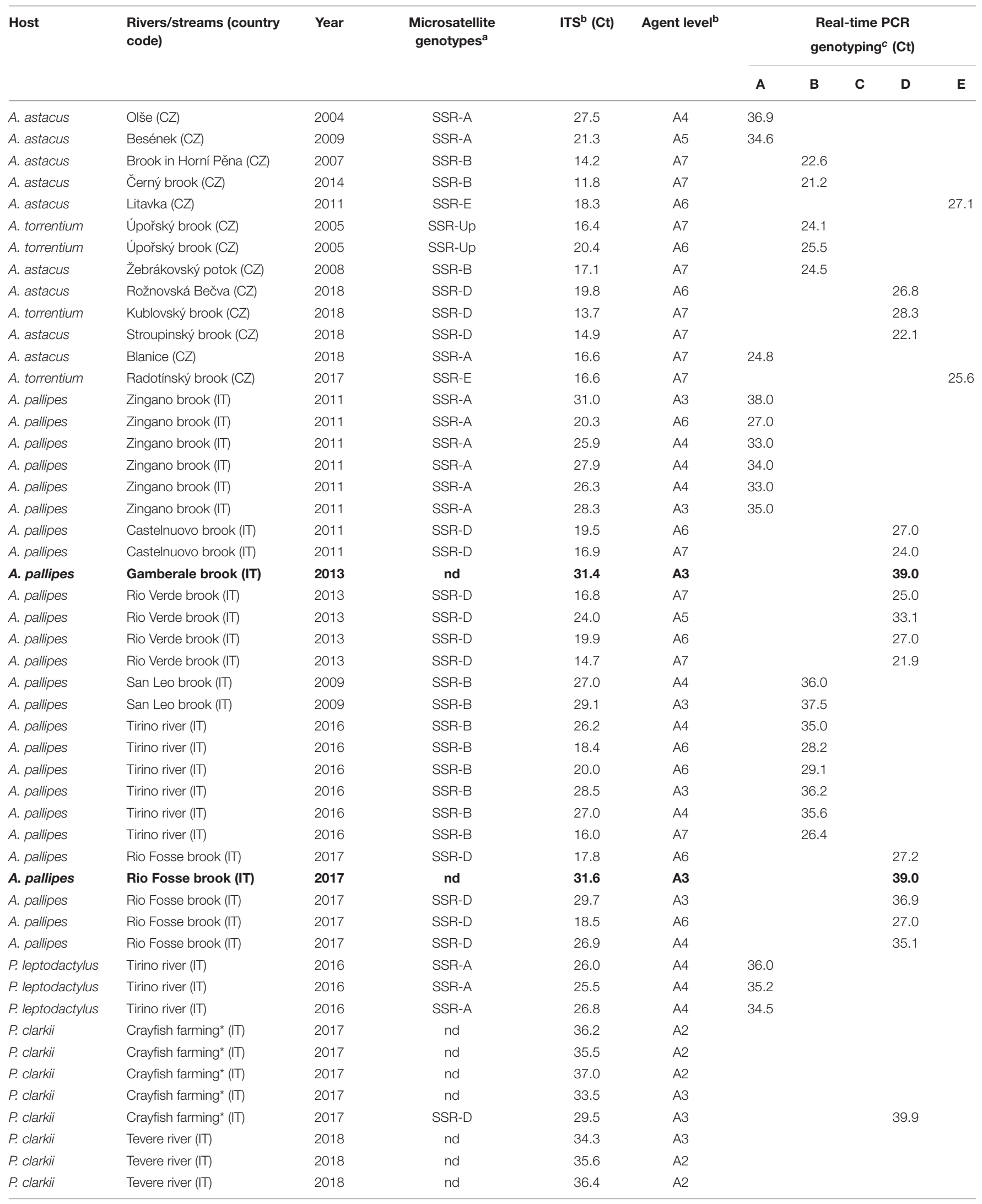


TABLE 3 | Continued

\begin{tabular}{|c|c|c|c|c|c|c|c|c|c|c|}
\hline \multirow[t]{2}{*}{ Host } & \multirow[t]{2}{*}{$\begin{array}{l}\text { Rivers/streams (country } \\
\text { code) }\end{array}$} & \multirow[t]{2}{*}{ Year } & \multirow[t]{2}{*}{$\begin{array}{l}\text { Microsatellite } \\
\text { genotypes }^{a}\end{array}$} & \multirow[t]{2}{*}{$\mathrm{ITS}^{b}(\mathrm{Ct})$} & \multirow[t]{2}{*}{ Agent level ${ }^{b}$} & \multicolumn{5}{|c|}{$\begin{array}{c}\text { Real-time PCR } \\
\text { genotyping }^{c}(\mathrm{Ct})\end{array}$} \\
\hline & & & & & & A & B & C & D & $\mathbf{E}$ \\
\hline P. clarkii & Papacqua lake (IT) & 2018 & nd & 33.0 & $\mathrm{~A} 3$ & & & & & \\
\hline P. clarkii & Papacqua lake (IT) & 2018 & nd & 33.6 & $\mathrm{~A} 3$ & & & & & \\
\hline P. clarkii & Crayfish farming* (IT) & 2018 & nd & 31.8 & A3 & & & & 38.4 & \\
\hline P. clarkii & Crayfish farming* (IT) & 2018 & nd & 31.4 & A3 & & & & 42.0 & \\
\hline P. clarkii & Crayfish farming ${ }^{\star}(\mathrm{IT})$ & 2018 & SSR-D & 30.4 & $\mathrm{~A} 3$ & & & & 38.1 & \\
\hline P. clarkii & Crayfish farming ${ }^{\star}(\mathrm{IT})$ & 2018 & nd & 33.4 & $\mathrm{~A} 3$ & & & & & \\
\hline P. clarkii & Crayfish farming* ${ }^{\star}$ (IT) & 2018 & SSR-D & 30.9 & A3 & & & & 37.3 & \\
\hline P. clarkii & Crayfish farming ${ }^{\star}(\mathrm{IT})$ & 2018 & nd & 31.4 & $\mathrm{~A} 3$ & & & & & \\
\hline P. clarkii & Crayfish farming ${ }^{\star}(\mathrm{IT})$ & 2018 & nd & 34.7 & $\mathrm{~A} 2$ & & & & & \\
\hline P. clarkii & Crayfish farming* $(\mathrm{IT})$ & 2018 & nd & 36.7 & $\mathrm{~A} 2$ & & & & & \\
\hline P. clarkii & Crayfish farming* $(\mathrm{IT})$ & 2018 & nd & 35.2 & $\mathrm{~A} 2$ & & & & & \\
\hline P. clarkii & Crayfish farming ${ }^{\star}$ (IT) & 2018 & nd & 31.5 & $\mathrm{~A} 3$ & & & & & \\
\hline P. clarkii & Crayfish farming ${ }^{\star}(\mathrm{IT})$ & 2018 & nd & 34.4 & $\mathrm{~A} 3$ & & & & & \\
\hline P. clarkii & Crayfish farming ${ }^{\star}(\mathrm{IT})$ & 2018 & SSR-D & 25.5 & A4 & & & & 35.8 & \\
\hline P. clarkii & Crayfish farming ${ }^{\star}$ (IT) & 2018 & nd & 33.5 & $\mathrm{~A} 3$ & & & & & \\
\hline F. rusticus & Big lake (WI) & 2016 & SSR-rust1 & 22.6 & A5 & & & 30.8 & & \\
\hline
\end{tabular}

${ }^{*}$ Crayfish farming Rocchetta al Volturno.

aMicrosatellite genotypes obtained according to the protocol described by Grandjean et al. (2014).

${ }^{b}$ Ct values and Agent levels obtained from the ITS real-time PCR Nrålstad et al., 2009).

${ }^{c}$ Ct values defined by the real-time PCR genotyping method described in this study.

Samples marked in bold are those for which genotyping was successful by real-time PCR only.

cross-reactivity with Leptolegnia caudata and Phoma-like isolates (Minardi et al., 2019).

Based on the data reported here, our real-time PCR assays seem specific for the RAPD-defined genotype groups A, D, and $\mathrm{E}$ (or DNA isolates with corresponding microsatellite multilocus genotypes) that are known to cause crayfish plague outbreaks in Europe; no cross-reactions were observed, either between different $A$. astaci isolates, in other oomycete strains isolated from crayfish, or in DNA extracted from field samples. The real-time PCR assay B identified all clinical samples assigned to SSR-B by microsatellite analysis, but also detected two samples classified as SSR-Up by microsatellite markers (Grandjean et al., 2014; Mojžišová et al., 2020).

The genotype group $\mathrm{C}$ assay amplified not only DNA of the respective $A$. astaci strain (Huang et al., 1994) but also DNA of $A$. fennicus and a DNA isolate obtained from F. rusticus infected by the "rust1" genotype (Panteleit et al., 2019). However, as group $C$ has not been documented in Europe since its original discovery (Ungureanu et al., 2020), the lack of specificity of assay $\mathrm{C}$ should be considered less relevant; in fact, rather than for the identification of a particular A. astaci genotype group, this assay can be used as an indicator of specific cases requiring further attention (i.e., the presence of unusual $A$. astaci genotypes or $A$. fennicus in a sample). Unfortunately, we failed to obtain any PCR products from A. fennicus that would allow sequencing of the anonymous nuclear marker targeted by this assay, so it is not possible to assess the extent of similarity of this genomic region between the respective strains of $A$. astaci and $A$. fennicus. In case of doubt, however, A. astaci genotype group $\mathrm{C}$ can be distinguished from A. fennicus by differences in the sequences of other molecular markers such as ITS (Viljamaa-Dirks and Heinikainen, 2019) and

TABLE 4 | Results of the duplex real-time PCR, with a comparison of the sensitivity expressed as Ct values with separate simplex reactions.

\begin{tabular}{|c|c|c|c|c|c|c|}
\hline \multirow[t]{2}{*}{ Host } & \multirow[t]{2}{*}{$\begin{array}{c}\text { Microsatellite } \\
\text { genotypes }\end{array}$} & \multirow[t]{2}{*}{$\begin{array}{l}\text { Simplex } \\
\text { (Ct) }\end{array}$} & \multicolumn{2}{|c|}{$\begin{array}{c}\text { Duplex A-B } \\
\text { (Ct) }\end{array}$} & \multicolumn{2}{|c|}{$\begin{array}{c}\text { Duplex D-E } \\
\text { (Ct) }\end{array}$} \\
\hline & & & A & B & D & $\mathbf{E}$ \\
\hline A. astacus & SSR-A & 24.8 & 25.5 & & & \\
\hline P. leptodactylus & SSR-A & 35.2 & 35.8 & & & \\
\hline A. pallipes & SSR-A & 27.0 & 28.7 & & & \\
\hline A. pallipes & SSR-B & 35.0 & & 35.1 & & \\
\hline A. pallipes & SSR-B & 29.1 & & 28.8 & & \\
\hline A. pallipes & SSR-B & 36.2 & & 36.3 & & \\
\hline A. pallipes & SSR-D & 33.1 & & & 33.2 & \\
\hline A. pallipes & SSR-D & 27.2 & & & 29.1 & \\
\hline P. clarkii & SSR-D & 35.8 & & & 38.2 & \\
\hline A. astacus & SSR-E & 27.1 & & & & 29.2 \\
\hline A. astacus & SSR-E & nd & & & & $\mathrm{Nd}$ \\
\hline A. torrentium & SSR-E & 25.6 & & & & 25.8 \\
\hline
\end{tabular}

Assays $A$ and $D$ were labeled with JOE, while $B$ and $E$ were labeled with FAM at the $5^{\prime}$ end.

Differences between simplex and duplex Ct values were not significant [paired t-test, $t(11)=-0.45 ; p=0.32]$.

Microsatellite genotypes obtained according to the protocol described by Grandjean et al. (2014). 
both mitochondrial ribosomal subunits (rnnS, rnnL; CasabellaHerrero et al., 2021).

The original reference strain of the RAPD-defined group C of A. astaci was isolated from Pacifastacus leniusculus (Huang et al., 1994). However, isolates showing some level of genetic similarity to this strain have been obtained from cambarid crayfish in the United States: axenic cultures matching the nuclear marker that Minardi et al. (2018) considered specific to group $\mathrm{C}$ have been isolated from Faxonius obscurus from Pennsylvania by Butler et al. (2020). Our results suggest that the "rust1" strain infecting F. rusticus (Panteleit et al., 2019) in Wisconsin also carries a marker sufficiently similar to be amplified by a TaqMan assay designed to detect the group C. This is in line with analyses of "rust1" laboratory cultures: they have a distinct profile of microsatellite nuclear markers (sharing most alleles with groups $\mathrm{C}$ and $\mathrm{B}$ ), and the sequences of mitochondrial rnnS and rnnL ribosomal subunits and a nuclear chitinase gene are identical with the reference strain of group C (Panteleit et al., 2019). Thus, although originally developed as specific for $A$. astaci genotype group $\mathrm{C}$, the real-time PCR assay developed by us may be rather used as a screening method for A. fennicus and for a wider range of unusual A. astaci genotypes. In any case, samples with positive detection by our assay $\mathrm{C}$ require additional detailed analyses, and the same is likely true when using the genotyping method described in Minardi et al. (2018). If A. fennicus is not involved, microsatellite markers from Grandjean et al. (2014), which fail to amplify in A. fennicus (Viljamaa-Dirks and Heinikainen, 2019), may be further used to characterize $A$. astaci strains positively reacting with our assay $\mathrm{C}$.

In terms of sensitivity, our real-time PCR assays allowed the genotyping of four samples for which microsatellite analysis failed (Table 4). These included a sample with agent level A3 from the 2013 outbreak in the Gamberale brook (near Agnone, Molise region), for which the causative genotype group was previously unknown. Unlike other outbreaks from Central Italy, only two dead crayfish were available from this site, with rather low amounts of pathogen DNA. Although we were unable to genotype this sample previously (Caprioli et al., 2018), the realtime PCR assay indicated that it belonged to group D.

Two samples from Úpořský brook (Czechia) deserve special attention when specificity of the group $B$ assay is considered. The $A$. astaci genotype that caused crayfish plague outbreak in that brook in 2005, since then also detected in chronically infected P. leptodactylus in the Danube (Panteleit et al., 2018) and additional recent outbreaks in Czechia (Mojžišová et al., 2020), is characterized by a consistent microsatellite pattern (SSR-Up). This differs from any known strains isolated to axenic cultures (and thus assigned to genotype groups by RAPD), but its microsatellite allele composition is most similar to strains representing genotype group B (Grandjean et al., 2014). Conversely, mitochondrial markers ( $\mathrm{rnnS}$ and $\mathrm{rnnL}$ ) assign this genotype to haplogroup A (Makkonen et al., 2018). Both SSR-Up isolates consistently yielded a positive signal in our group $B$ real-time PCR assay. In these cases, the combination of real-time PCR targeting the nuclear loci and mtDNA sequencing would allow distinguishing this particular A. astaci genotype from strains of genotype group B.

Although less important than specificity and sensitivity, it is worth reporting that the time needed to perform the real-time PCR analysis proposed here is greatly reduced, thanks to the use of rapid PCR protocols and duplexing the reactions targeting the four widespread genotype groups causing most crayfish plague outbreaks in European countries (A, B, D, and E).

Despite these benefits, the substantial limitation of the new method remains sensitivity, which apparently does not exceed that obtained by sequencing multicopy mitochondrial markers (Makkonen et al., 2018). Indeed, although our method allowed us to characterize four A3-level samples that we were unable to genotype by microsatellite analysis, other A3 samples could not be characterized. Samples with A3 agent levels fall within a wide range of $\mathrm{Ct}$ values (28-35), so the lower the $\mathrm{Ct}$, the higher the probability the sample is successfully genotyped. This is because the ITS target region used in quantitative PCR to assign the agent level is a multicopy target (Vrålstad et al., 2009), whereas the five assays described in this study were designed on presumably single-copy genes. Amplification of the target marker in a $\mathrm{qPCR}$ reaction nevertheless allows the detection of smaller amounts of the target DNA than is required for successful characterization in fragment analyses used for microsatellite genotyping.

Overall, however, the use of real-time PCR assays for genotyping purposes has multiple advantages. The method speeds up genetic characterization of $A$. astaci DNA extracted directly from crayfish-infected tissues, it is easy to perform, the interpretation of results is unambiguous (positive/negative) and highly reproducible, and the likelihood of laboratory contamination by PCR products is reduced. Once a genotype group is indicated, samples amplified by group $B$ and $C$ assays may be further investigated, taking advantage of other currently available methods. For example, after a positive detection by our group B real-time PCR assay, samples belonging to the RAPD-defined group B may be differentiated from the "SSRUp" genotype by fragment analysis of diagnostic microsatellite loci (Grandjean et al., 2014; Mojžišová et al., 2020) and/or by sequencing the mitochondrial $\mathrm{rnnS}$ or chitinase genes (Panteleit et al., 2018). In conclusion, the different genotyping methods available for $A$. astaci, including the real-time PCR approach described in this study, may thus conveniently complement each other.

\section{DATA AVAILABILITY STATEMENT}

The data that support the findings of this study are available from the corresponding author upon request.

\section{AUTHOR CONTRIBUTIONS}

MDD, VC, and AP: conceptualization. MDD: data curation. MDD, VC, AP, and CC: formal analysis. CC, CG, and AP: funding acquisition. RC, VC, AM, MM, and MDD: investigation. 
MDD, VC, AP, CC, CG, MM, AM, and RC: methodology. MDD and VC: software. CC and AP: supervision. RC, VC, and MDD: writing-original draft. AP and MDD: writing-review and editing. All authors have read and agreed to the published version of the manuscript.

\section{FUNDING}

The research was supported by the Italian Ministry of Health (project IZS AM 06/16 RC) and Charles University, Prague (project SVV 260569). AM acknowledges financial support from the Alexander von Humboldt Foundation.

\section{REFERENCES}

Alderman, D. J. (1996). Geographical spread of bacterial and fungal diseases of crustaceans. Rev. Sci. Tech. 15, 603-632. doi: 10.20506/rst.15.2.943

Alker, A. P., Mwapasa, V., and Meshnick, S. R. (2004). Rapid real-time PCR genotyping of mutations associated with sulfadoxine-pyrimethamine resistance in Plasmodium falciparum. Antimicrob. Agents Chemother. 48, 2924-2929.

Ballesteros, I., Martín, M. P., and Diéguez-Uribeondo, J. (2006). First isolation of Aphanomyces frigidophilus (Saprolegniales) in Europe. Mycotaxon 95, 335-340.

Becking, T., Mrugała, A., Delaunay, C., Svoboda, J., Raimond, M., ViljamaaDirks, S., et al. (2015). Effect of experimental exposure to differently virulent Aphanomyces astaci strains on the immune response of the noble crayfish Astacus astacus. J. Invertebr. Pathol. 132, 115-124. doi: 10.1016/j.jip.2015.08. 007

Birdsell, D. N., Vogler, A. J., Buchhagen, J., Clare, A., Kaufman, E., Naumann, A., et al. (2014). TaqMan real-time PCR assays for single-nucleotide polymorphisms which identify Francisella tularensis and its subspecies and subpopulations. PLoS One 9:e107964. doi: 10.1371/journal.pone.0107964

Bohman, P., Nordwall, F., and Edsman, L. (2006). The effect of the largescale introduction of signal crayfish on the spread of crayfish plague in Sweden. Bull. Fr. Pêche Piscicul. 380-381, 1291-1302. doi: 10.1051/kmae:20 06026

Butler, E., Crigler, P., Robbins, G., and Blair, J. E. (2020). Preliminary survey of Aphanomyces sp. associated with native and invasive crayfish in the Lower Susquehanna watershed of South Central Pennsylvania. J. Freshw. Ecol. 35, 223-233. doi: 10.1080/02705060.2020.1779141

Cammà, C., Ferri, N., Zezza, D., Marcacci, M., Paolini, A., Ricchiuti, L., et al. (2010). Confirmation of crayfish plague in Italy: detection of Aphanomyces astaci in white clawed crayfish. Dis. Aquat. Org. 89, 265-268. doi: 10.3354/ dao02207

Caprioli, R., Cargini, D., Marcacci, M., Cammà, C., Giansante, C., and Ferri, N. (2013). Self-limiting outbreak of crayfish plague in an Austropotamobius pallipes population of a river basin in the Abruzzi region (Central Italy). Dis. Aquat. Org. 103, 149-156. doi: 10.3354/dao02571

Caprioli, R., Mrugała, A., Di Domenico, M., Curini, V., Giansante, C., Cammà, C., et al. (2018). Aphanomyces astaci genotypes involved in recent crayfish plague outbreaks in central Italy. Dis. Aquat. Org. 130, 209-219. doi: 10.3354/ dao 03275

Casabella-Herrero, G., Martínez-Ríos, M., Viljamaa-Dirks, S., Martín-Torrijos, L., and Diéguez-Uribeondo, J. (2021). Aphanomyces astaci mtDNA: insights into the pathogen's differentiation and its genetic diversity from other closely related oomycetes. Fungal Biol. 125, 316-325. doi: 10.1016/j.funbio. 2020.11.010

Diéguez-Uribeondo, J. (2006). Dispersion of the Aphanomyces astaci-carrier, Pacifastacus leniusculus, by humans represents the main cause of disappearance of native populations of Austropotamobius pallipes in Navarra. Bull. Fr. Pêche Piscicul. 4, 1303-1312. doi: 10.1051/kmae:2006036

\section{ACKNOWLEDGMENTS}

We thank Satu Viljamaa-Dirks for providing A. fennicus and $A$. astaci isolate Kv1 DNA (with the permission of Kenneth Söderhäll) from the collections of the Finnish Food Authority Ruokavirasto (Kuopio), Javier Diéguez-Uribeondo for permission to analyze DNA isolates of oomycetes from the collections of Real Jardín Botánico, CSIC, Madrid (isolates with SAP codes), Jenny Makkonen for DNA of Aphanomyces spp. cultures isolated from Lake Tahoe signal crayfish, and Anne Schrimpf for a DNA isolate of infected Faxonius rusticus from the United States. David Hardekopf is acknowledged for language revisions of the final version of the manuscript.

Diéguez-Uribeondo, J., and Söderhäll, K. (1993). Procambarus clarkii as a vector for the crayfish plague fungus Aphanomyces astaci Schikora. Aquac. Fish. Manage. $24,761-765$.

Diéguez-Uribeondo, J., García, M. A., Cerenius, L., Kozubíková, E., Ballesteros, I., Windels, C., et al. (2009). Phylogenetic relationships among plant and animal parasites, and saprotrophs in Aphanomyces (Oomycetes). Fungal Genet. Biol. 46, 365-376. doi: 10.1016/j.fgb.2009.02.004

Diéguez-Uribeondo, J., Huang, T., Cerenius, L., and Söderhäll, K. (1995). Physiological adaptation of an Aphanomyces astaci strain isolated from the freshwater crayfish Procambarus clarkii. Mycol. Res. 99, 574-578. doi: 10.1016/ s0953-7562(09)80716-8

Filipová, L., Petrusek, A., Matasová, K., Delaunay, C., and Grandjean, F. (2013). Prevalence of the crayfish plague pathogen Aphanomyces astaci in populations of the signal crayfish Pacifastacus leniusculus in France: evaluating the threat to native crayfish. PLoS One 8:e70157. doi: 10.1371/journal.pone. 0070157

Grandjean, F., Vrålstad, T., Diéguez-Uribeondo, J., Jelić, M., Mangombi, J., Delaunay, C., et al. (2014). Microsatellite markers for direct genotyping of the crayfish plague pathogen Aphanomyces astaci (Oomycetes) from infected host tissues. Vet. Microbiol. 170, 317-324. doi: 10.1016/j.vetmic.2014.02.020

Holdich, D. M., Reynolds, J. D., Souty-Grosset, C., and Sibley, P. J. (2009). A review of the ever increasing threat to European crayfish from non-indigenous crayfish species. Knowl. Manag. Aquat. Ecosyst. 394-395:11. doi: 10.1051/kmae/ 2009025

Hsieh, C. Y., Huang, C. W., and Pan, Y. C. (2016). Crayfish plague Aphanomyces astaci detected in redclaw crayfish, Cherax quadricarinatus in Taiwan. J. Invertebr. Pathol. 136, 117-123. doi: 10.1016/j.jip.2016.03.015

Huang, T., Cerenius, L., and Söderhäll, K. (1994). Analysis of genetic diversity in the crayfish plague fungus, Aphanomyces astaci, by random amplification of polymorphic DNA. Aquaculture 126, 1-9. doi: 10.1016/00448486(94)90243-7

James, J., Mrugała, A., Oidtmann, B., Petrusek, A., and Cable, J. (2017). Apparent interspecific transmission of Aphanomyces astaci from invasive signal to virile crayfish in a sympatric wild population. J. Invertebr. Pathol. 145, 68-71. doi: 10.1016/j.jip.2017.02.003

Jussila, J., Vrezec, A., Makkonen, J., Kortet, R., and Kokko, H. (2015). “Invasive crayfish and their invasive diseases in Europe with the focus on the virulence evolution of the crayfish plague," in Biological Invasions in Changing Ecosystems. Vectors, Ecological Impacts, Management and Predictions, ed. J. Canning-Clode (Warsaw: De Gruyter).

Kaldre, K., Paaver, T., Hurt, M., and Grandjean, F. (2017). First records of the non-indigenous signal crayfish (Pacifastacus leniusculus) and its threat to noble crayfish (Astacus astacus) populations in Estonia. Biol. Invasions 19, 2771-2776. doi: 10.1007/s10530-017-1496-z

Kokko, H., Harlioglu, M. M., Aydin, H., Makkonen, J., Gökmen, G., Aksu, Ö, et al. (2018). Observations of crayfish plague infections in commercially important narrow-clawed crayfish populations in Turkey. Knowl. Manag. Aquat. Ecosyst. 419:10. doi: 10.1051/kmae/2018001 
Kouba, A., Petrusek, A., and Kozák, P. (2014). Continental-wide distribution of crayfish species in Europe: update and maps. Knowl. Manag. Aquat. Ecosyst. 413:05. doi: 10.1051/kmae $/ 2014007$

Kozubíková, E., Petrusek, A., Ďuriš, Z., Martín, M. P., Diéguez-Uribeondo, J., and Oidtmann, B. (2008). The old menace is back: recent crayfish plague outbreaks in the Czech Republic. Aquaculture 274, 208-217. doi: 10.1016/j.aquaculture. 2007.11.015

Kozubíková, E., Viljamaa-Dirks, S., Heinikainen, S., and Petrusek, A. (2011a). Spiny-cheek crayfish Orconectes limosus carry a novel genotype of the crayfish plague pathogen Aphanomyces astaci. J. Invertebr. Pathol. 108, 214-216. doi: 10.1016/j.jip.2011.08.002

Kozubíková, E., Vrålstad, T., Filipová, L., and Petrusek, A. (2011b). Reexamination of the prevalence of Aphanomyces astaci in North American crayfish populations in Central Europe by TaqMan MGB real-time PCR. Dis. Aquat. Org. 97, 113-125. doi: 10.3354/dao02411

Kozubíková-Balcarová, E., Beran, L., Ďuriš, Z., Fischer, D., Horká, I., Svobodová, J., et al. (2014). Status and recovery of indigenous crayfish populations after recent crayfish plague outbreaks in the Czech Republic. Ethol. Ecol. Evol. 26, 299-319. doi: 10.1080/03949370.2014.897652

Kozubíková-Balcarová, E., Koukol, O., Martín, M. P., Svoboda, J., Petrusek, A., and Diéguez-Uribeondo, J. (2013). The diversity of oomycetes on crayfish: Morphological vs. molecular identification of cultures obtained while isolating the crayfish plague pathogen. Fungal Biol. 117, 682-691. doi: 10.1016/j.funbio. 2013.07.005

Maguire, I., Jelić, M., Klobučar, G., Delpy, M., Delaunay, C., and Grandjean, F. (2016). Prevalence of the pathogen Aphanomyces astaci in freshwater crayfish populations in Croatia. Dis. Aquat. Org. 118, 45-53. doi: 10.3354/dao02955

Makkonen, J., Jussila, J., Panteleit, J., Keller, N. S., Schrimpf, A., Theissinger, K., et al. (2018). MtDNA allows the sensitive detection and haplotyping of the crayfish plague disease agent Aphanomyces astaci showing clues about its origin and migration. Parasitology 26, 1-9. doi: 10.1017/S0031182018000227

Makkonen, J., Kokko, H., Gökmen, G., Ward, J., Umek, J., Kortet, R., et al. (2019). The signal crayfish (Pacifastacus leniusculus) in Lake Tahoe (USA) hosts multiple Aphanomyces species. J. Invertebr. Pathol. 166:107218. doi: 10.1016/j. jip.2019.107218

Martín-Torrijos, L., Kawai, T., Makkonen, J., Jussila, J., Kokko, H., and DiéguezUribeondo, J. (2018). Crayfish plague in Japan: a real threat to the endemic Cambaroides japonicus. PLoS One 13:e0195353. doi: 10.1371/journal.pone. 0195353

Martín-Torrijos, L., Kokko, H., Makkonen, J., Jussila, J., and Diéguez-Uribeondo, J. (2019). Mapping 15 years of crayfish plague in the Iberian Peninsula: the impact of two invasive species on the endangered native crayfish. PLoS One 14:e0219223. doi: 10.1371/journal.pone.0219223

Martín-Torrijos, L., Martínez-Ríos, M., Casabella-Herrero, G., Adams, S. B., Jackson, C. R., and Diéguez-Uribeondo, J. (2021). Tracing the origin of the crayfish plague pathogen, Aphanomyces astaci, to the Southeastern United States. Sci. Rep. 11:9332. doi: 10.1038/s41598-021-88704-8

Minardi, D., Studholme, D. J., Oidtmann, B., Pretto, T., and van der Giezen, M. (2019). Improved method for genotyping the causative agent of crayfish plague (Aphanomyces astaci) based on mitochondrial DNA. Parasitology 146, 1022-1029. doi: 10.1017/S0031182019000283

Minardi, D., Studholme, D. J., van der Giezen, M., Pretto, T., and Oidtmann, B. (2018). New genotyping method for the causative agent of crayfish plague (Aphanomyces astaci) based on whole genome data. J. Invertebr. Pathol. 156, 6-13. doi: 10.1016/j.jip.2018.06.002

Mojžišová, M., Mrugała, A., Kozubíková-Balcarová, E., Vlach, P., Svobodová, J., Kouba, A., et al. (2020). Crayfish plague in Czechia: outbreaks from novel sources and testing for chronic infections. J. Invertebr. Pathol. 173:107390. doi: 10.1016/j.jip.2020.107390

Mrugała, A., Kawai, T., Kozubíková-Balcarová, E., and Petrusek, A. (2017a). Aphanomyces astaci presence in Japan: a threat to the endemic and endangered crayfish species Cambaroides japonicus? Aquat. Conserv. 27, 103-114. doi: 10. $1002 /$ aqc. 2674

Mrugała, A., Kozubíková-Balcarová, E., Chucholl, C., Cabanillas Resino, S., Viljamaa-Dirks, S., Vukić, J., et al. (2015). Trade of ornamental crayfish in Europe as a possible introduction pathway for important crustacean diseases: crayfish plague and white spot syndrome. Biol. Invasions 17, 1313-1326. doi: 10.1007/s10530-014-0795-x
Mrugała, A., Šanda, R., Petrusek, A., Marić, D., and Vukić, J. (2017b). Recent acute crayfish mortality reveals Aphanomyces astaci presence in Bosnia and Herzegovina. J. Invertebr. Pathol. 150, 73-75. doi: 10.1016/j.jip.2017. 09.004

Oidtmann, B., Cerenius, L., Schmid, I., Hoffmann, R., and Söderhäll, K. (1999). Crayfish plague epizootics in Germany-classification of two German isolates of the crayfish plague fungus Aphanomyces astaci by random amplification of polymorphic DNA. Dis. Aquat. Org. 35, 235-238. doi: 10.3354/ dao 035235

OIE (World Organisation for Animal Health) (2019). Manual of Diagnostic Tests for Aquatic Animals. Available online at: https:/www.oie.int/standard-setting/ aquatic-manual (accessed August 06, 2020).

Panteleit, J., Horvath, T., Jussila, J., Makkonen, J., Perry, W., Schulz, R., et al. (2019). Invasive rusty crayfish (Faxonius rusticus) populations in North America are infected with the crayfish plague disease agent (Aphanomyces astaci). Freshw. Sci. 38, 425-433. doi: 10.1086/703417

Panteleit, J., Keller, N. S., Diéguez-Uribeondo, J., and Makkonen, J. (2018). Hidden sites in the distribution of the crayfish plague pathogen Aphanomyces astaci in Eastern Europe: relicts of genetic groups from older outbreaks? J. Invertebr. Pathol. 157, 117-124. doi: 10.1016/j.jip.2018.05.006

Peiró, D. F., Almerão, M. P., Delaunay, C., Jussila, J., Makkonen, J., Bouchon, D., et al. (2016). First detection of the crayfish plague pathogen Aphanomyces astaci in South America: a high potential risk to native crayfish. Hydrobiologia 781, 181-190. doi: 10.1007/s10750-016-2841-4

Persson, M., and Söderhäll, K. (1983). Pacifastacus leniusculus Dana and its resistance to the parasitic fungus Aphanomyces astaci Schikora. Freshw. Crayfish 5, 292-298.

Putra, M. D., Bláha, M., Wardiatno, Y., Krisanti, M., Yonvitner, Jerikho, R., et al. (2018). Procambarus clarkii (Girard, 1852) and crayfish plague as new threats for biodiversity in Indonesia. Aquat. Conserv. Mar. Freshw. Ecosys. 28, 1434-1440. doi: 10.1002/aqc.2970

Rezinciuc, S., Galindo, J., Montserrat, J., and Diéguez-Uribeondo, J. (2014). AFLP-PCR and RAPD-PCR evidences of the transmission of the pathogen Aphanomyces astaci (Oomycetes) to wild populations of European crayfish from the invasive crayfish species, Procambarus clarkii. Fungal Biol. 118, 612620. doi: 10.1016/j.funbio.2013.10.007

Rezinciuc, S., Sandoval-Sierra, J. V., Oidtmann, B., and Diéguez-Uribeondo, J. (2015). "The biology of crayfish plague pathogen: current answers to most frequent questions," in Freshwater Crayfish: A Global Overview, eds T. Kawai, Z. Faulkes, and G. Scholtz (Boca Raton, FL: CRC Press), 182-204.

Schrimpf, A., Pârvulescu, L., Copilaş-Ciocianu, D., Petrusek, A., and Schulz, R. (2012). Crayfish plague pathogen detected in the Danube Delta - a potential threat to freshwater biodiversity in southeastern Europe. Aquat. Invasions 7, 503-510. doi: 10.3391/ai.2012.7.4.007

Svoboda, J., Mrugała, A., Kozubíková-Balcarová, E., and Petrusek, A. (2017). Hosts and transmission of the crayfish plague pathogen Aphanomyces astaci: a review. J. Fish. Dis. 40, 127-140. doi: $10.1111 /$ jfd. 12472

Unestam, T. (1969). Resistance to the crayfish plague fungus in some American, Japanese and European crayfish. Rep. Inst. Freshw. Res. Drottningholm 49, 202-209.

Unestam, T. (1972). On the host range and origin of the crayfish plague fungus. Rep. Inst. Freshw. Res. Drottningholm 52, 192-198.

Unestam, T., and Weiss, D. W. (1970). The host-parasite interaction relationship between freshwater crayfish and the crayfish disease fungus Aphanomyces astaci: responses to infection by susceptible and resistant species. J. Gen. Microbiol. 60, 77-90. doi: 10.1099/00221287-60-1-77

Ungureanu, E., Mojžišová, M., Tangerman, M., Ion, M. C., Pârvulescu, L., and Petrusek, A. (2020). The spatial distribution of Aphanomyces astaci genotypes across Europe: introducing the first data from Ukraine. Freshw. Crayfish 25, 77-87. doi: 10.5869/fc.2020.v25-1.077

Vey, A., Söderhäll, K., and Ajaxon, R. (1983). Susceptibility of Orconectes limosus Raff. to crayfish plague. Freshw. Crayfish 5, 192-291.

Viljamaa-Dirks, S., and Heinikainen, S. (2019). A tentative new species Aphanomyces fennicus sp. nov. interferes with molecular diagnostic methods for crayfish plague. J. Fish. Dis. 42, 413-422. doi: 10.1111/jfd.12955

Viljamaa-Dirks, S., Heinikainen, S., Torssonen, H., Pursiainen, M., Mattila, J., and Pelkonen, S. (2013). Distribution and epidemiology of genotypes of the 
crayfish plague agent Aphanomyces astaci from noble crayfish Astacus astacus in Finland. Dis. Aquat. Org. 103, 199-208. doi: 10.3354/dao02575

Vrålstad, T., Knutsen, A. K., Tengs, T., and Holst-Jensen, A. (2009). A quantitative TaqMan MGB real-time polymerase chain reaction based assay for detection of the causative agent of crayfish plague Aphanomyces astaci. Vet. Microbiol. 137, 146-155. doi: 10.1016/j.vetmic.2008.12.022

Vrålstad, T., Strand, D. A., Grandjean, F., Kvellestad, A., Håstein, T., Knutsen, A., et al. (2014). Molecular detection and genotyping of Aphanomyces astaci directly from preserved crayfish samples uncovers the Norwegian crayfish plague disease history. Vet. Microbiol. 173, 66-75. doi: 10.1016/j.vetmic.2014. 07.008
Conflict of Interest: The authors declare that the research was conducted in the absence of any commercial or financial relationships that could be construed as a potential conflict of interest.

Copyright (๑) 2021 Di Domenico, Curini, Caprioli, Giansante, Mrugała, Mojžǐ̌ová, Cammà and Petrusek. This is an open-access article distributed under the terms of the Creative Commons Attribution License (CC BY). The use, distribution or reproduction in other forums is permitted, provided the original author(s) and the copyright owner(s) are credited and that the original publication in this journal is cited, in accordance with accepted academic practice. No use, distribution or reproduction is permitted which does not comply with these terms. 